\title{
Design of a Quantitative LC-MS Method for Residual Toxins Adenylate Cyclase Toxin (ACT), Dermonecrotic Toxin (DNT) and Tracheal Cytotoxin (TCT) in Bordetella pertussis Vaccines
}

\author{
Lisa Szymkowicz (D), Jeffery Gerard (D), Benjamin Messham, Wai Wan Vivian Tam and D. Andrew James *(D) \\ MS/NMR Center, Analytical Sciences, Sanofi Pasteur Ltd., Toronto, ON M2R 3T4, Canada; \\ lisa.szymkowicz@sanofi.com (L.S.); benjamin.messham@sanofi.com (B.M.) \\ * Correspondence: andrew.james@sanofi.com
}

Citation: Szymkowicz, L.; Gerard, J.; Messham, B.; Tam, W.W.V.; James, D.A. Design of a Quantitative LC-MS Method for Residual Toxins Adenylate Cyclase Toxin (ACT), Dermonecrotic Toxin (DNT) and Tracheal Cytotoxin (TCT) in Bordetella pertussis Vaccines. Toxins 2021, 13, 763. https://doi.org/10.3390/ toxins13110763

Received: 30 September 2021

Accepted: 25 October 2021

Published: 28 October 2021

Publisher's Note: MDPI stays neutral with regard to jurisdictional claims in published maps and institutional affiliations.

Copyright: (c) 2021 by the authors. Licensee MDPI, Basel, Switzerland. This article is an open access article distributed under the terms and conditions of the Creative Commons Attribution (CC BY) license (https:// creativecommons.org/licenses/by/ $4.0 /)$.

\begin{abstract}
The antigens for acellular pertussis vaccines are made up of protein components that are purified directly from Bordetella pertussis (B. pertussis) bacterial fermentation. As such, there are additional B. pertussis toxins that must be monitored as residuals during process optimization. This paper describes a liquid chromatography mass spectrometry (LC-MS) method for simultaneous analysis of residual protein toxins adenylate cyclase toxin (ACT) and dermonecrotic toxin (DNT), as well as a small molecule glycopeptide, tracheal cytotoxin (TCT) in a Pertussis toxin vaccine antigen. A targeted LC-MS technique called multiple reaction monitoring (MRM) is used for quantitation of ACT and TCT, which have established limits in drug product formulations. However, DNT is currently monitored in an animal test, which does not have an established quantitative threshold. New approaches for DNT testing are discussed, including a novel standard based on concatenated quantitation sequences for ACT and DNT. Collectively, the method represents a "3-in-1" analytical simplification for monitoring process-related residuals during development of B. pertussis vaccines.
\end{abstract}

Keywords: Bordetella pertussis; adenylate cyclase toxin; dermonecrotic toxin; tracheal cytotoxin; pertussis toxin; quantitative LC-MS; mass spectrometry; vaccine

Key Contribution: A quantitative liquid chromatography mass spectrometry (LC-MS) method for simultaneous analysis of residual toxins adenylate cyclase toxin (ACT), dermonecrotic toxin (DNT), and tracheal cytotoxin (TCT). Method performance is described for a Pertussis toxin (PT) vaccine antigen.

\section{Introduction}

Pertussis disease, commonly known as whooping cough, is a highly infectious respiratory disease caused by the bacterium Bordetella pertussis. After initial infection and cold-like symptoms the disease may progress to a phase characterized by a paroxysmal fit of coughing followed by a distinctive "whooping" inhalation breath; in infants and young children the disease can be lethal. The first effective vaccines for prevention of this disease were developed nearly a century ago in the 1930s using inactivated whole-cell B. pertussis bacteria [1,2]. In the 1980s, due to the reactogenicity of this type of vaccine and increasing vaccine hesitancy, whole cell pertussis $(\mathrm{wP})$ vaccines were supplanted in Western nations with acellular pertussis (aP) vaccines comprised of purified antigenic protein components from the bacterium [3-5]. Despite the long history of both the wP and $\mathrm{aP}$ vaccines, the disease remains a major public health concern, with nearly 60 thousand deaths (2015) and the largest disease burden among children less than five years in developing countries [6,7]. Neither infection or vaccination confers life-long immunity [8] and current recommendations include five vaccinations before age seven and a booster shot between ages 11 and 18 [9]. Acellular vaccines are as efficacious as wP vaccines; however, 
the protection provided by acellular vaccines declines faster [10]. This has increased interest in developing new Pertussis vaccines [11-13].

The aP vaccines are typically comprised of protein antigens purified from B. pertussis cultures, including pertussis toxin (PT) and other virulence adhesin proteins such as fimbria, pertactin, and filamentous haemagglutinin $[14,15]$. Because the antigens are produced from fermentations of the causative agent, there are other toxins that can co-purify; it is important that these additional toxins are controlled during development and refinement of purification processes for $\mathrm{aP}$ vaccines. These process related impurities include adenylate cyclase toxin (ACT) $[16,17]$ and dermonecrotic toxin (DNT) $[18,19]$, as well as the secondary metabolite tracheal cytotoxin (TCT) [20-22]. It is important to monitor these residual toxins and show clearance after antigen purification [23,24].

Both the European Pharmacopeia (Ph. Eur) and World Health Organization (WHO) provide testing and limit guidelines for these residual toxins (Supplement S1). As per $\mathrm{Ph} \mathrm{Eu} .1356$ [23], the ACT concentration must be less than 500 ng per dose, determined by immunoblot analysis or other suitable methods. This can be achieved using an EnzymeLinked Immunosorbent Assay (ELISA) or using a cell-free enzymatic method [24]. The same EU guideline provide limits for TCT concentration, which must be less than 2 pmol per dose as determined by a biological assay or liquid chromatography (LC). However, unlike $\mathrm{ACT}$ and TCT, where regulatory limits have been quantitatively defined, the current regulatory standard for DNT involves an in vivo mouse test for Absence of Residual DNT with a simple pass/fail criterion. Though the pharmaceutical and vaccine industries strive towards reduction, refinement, and replacement of animal safety tests $[25,26]$, to date no in vitro alternative has been accepted by health authorities for DNT testing, and it will continue to pose a challenge until a quantitative limit can be defined.

Previously, we reported the development of a targeted nano-LC tandem mass spectrometry (MS/MS) method for quantitation of ACT and DNT residual toxins from B. pertussis [27]. Herein we describe the design and qualification of a higher throughput LC-MS/MS method for detection and quantitation of ACT, DNT, and TCT. For protein toxins ACT and DNT, a surrogate peptide approach was used with stable isotopically labelled Absolute Quantitation (AQUA ${ }^{\mathrm{TM}}$ ) standards for protein quantitation. However, TCT presented a different challenge because it is a secondary metabolite and not a protein. Although traditional organic synthesis of TCT is possible [28], this approach is not as convenient as isotopically labelled AQUA peptide sequences using standard heavy labelled amino acids. Hence, for TCT, we describe the development and qualification of a more traditional, small molecule quantitation approach using an external calibration curve. Implementation of high flow ultra-performance liquid chromatography (UPLC) coupled to multiple reaction monitoring (MRM) enabled simultaneous monitoring of all three residual toxins pertinent to the safety of aP vaccines using a single analytical workflow (Figure 1).
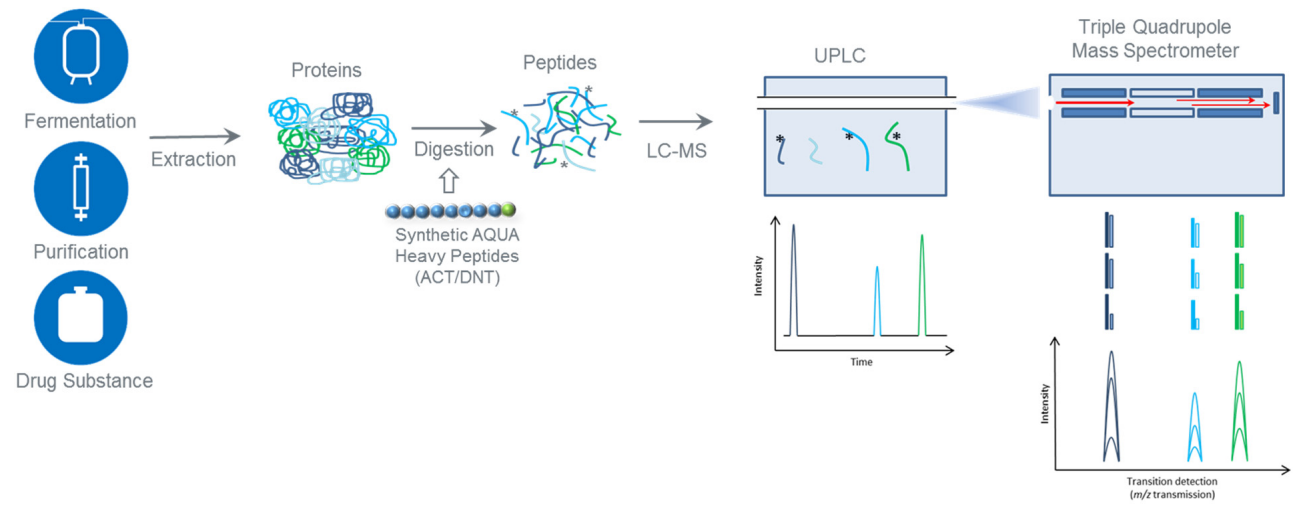

Figure 1. LC-MRM workflow for quantitation of residual toxins from B. pertussis across manufacturing stages of aP vaccines. Schematic includes protein extraction, digestion, separation by UPLC and MRM on a Xevo ${ }^{\text {TM }}$ Tandem QuadrupoleStepwave (TQ-S) mass spectrometer. Solutions containing purified TCT standard are run using the MRM method to generate a calibration curve. 


\section{Results}

\subsection{TCT Detection in B. pertussis Supernatant Harvest}

Tracheal cytotoxin was detected via nanoLC-MS/MS analysis of B. pertussis supernatant harvest digest. The singly charged $[\mathrm{M}+\mathrm{H}] \mathrm{TCT}$ precursor was isotopically resolved in the high-resolution mass spectrometry (HRMS) survey scan (Figure 2a). The monoisotopic peak detected at $922.3891 \mathrm{~m} / \mathrm{z}$ was a close match to the theoretical [M $+\mathrm{H}]$ mass of $922.3893 \mathrm{~m} / \mathrm{z}$.

(A)

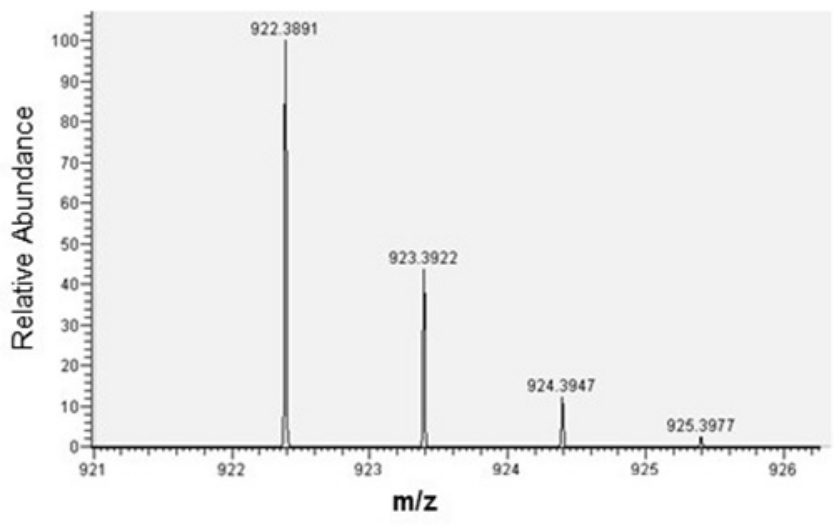

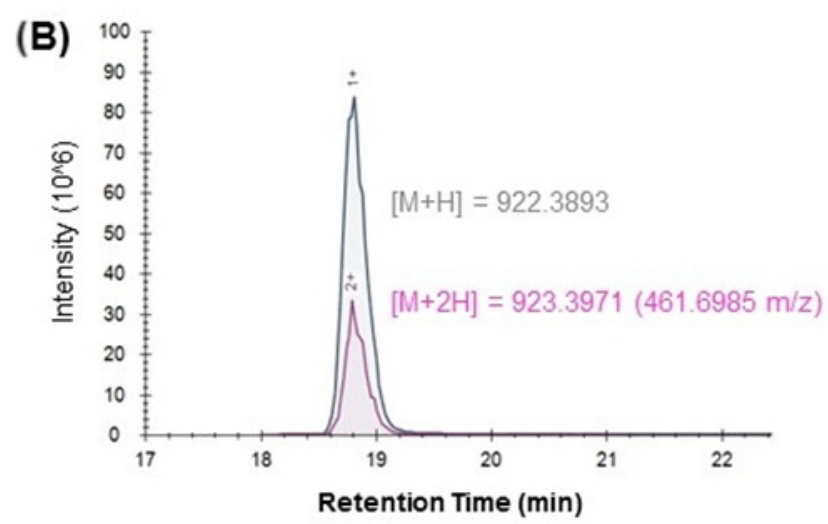

(C)

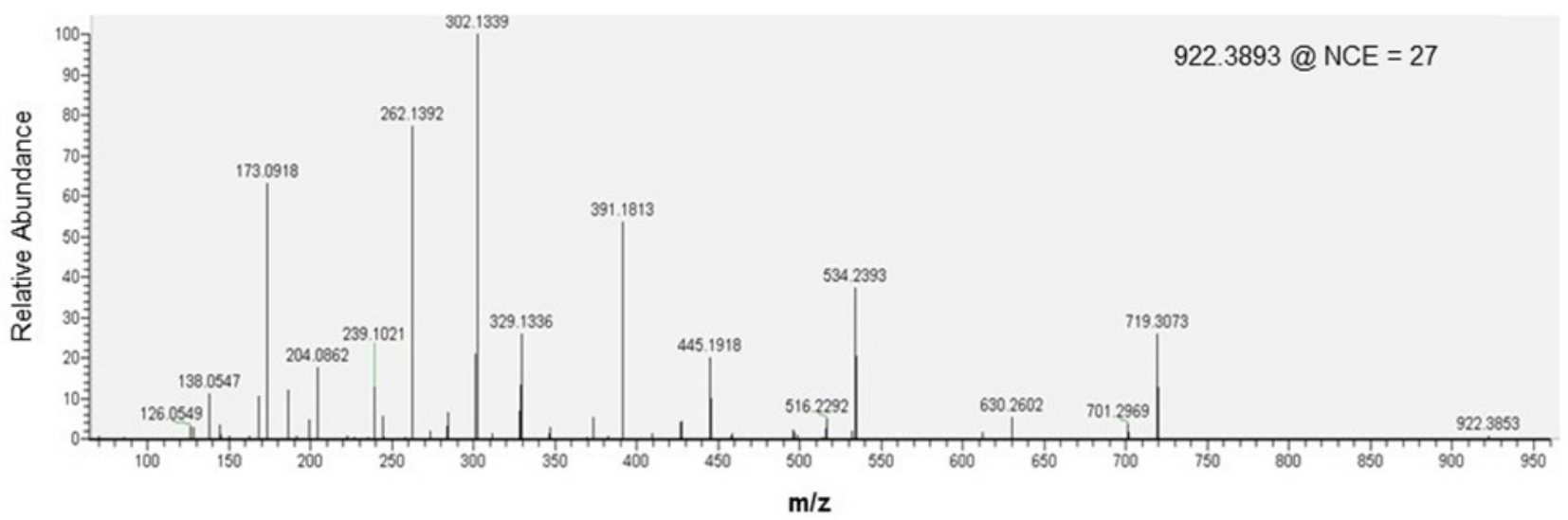

Figure 2. TCT detection in B. pertussis supernatant harvest digest. (A) High-resolution MS1 survey scan, (B) Extracted ion chromatogram (XIC) for singly and doubly charged precursors, and (C) MS/MS generated from high-energy C-trap dissociation (HCD) of the singly charged TCT precursor. Refer to Supplement S6 for TCT fragment ion annotation.

Retention times variability of the TCT peak on reverse phase nano-LC C18 was observed between acquisitions. This could be attributed to weak analyte binding to $\mathrm{C} 18$ with elution at approximately $6 \%(v / v)$ mobile phase B (0.1\% FA in ACN). Additional specify was confirmed by co-elution of the singly and doubly charged TCT precursor ions at $922.3893 \mathrm{~m} / \mathrm{z}$ and $461.6985 \mathrm{~m} / \mathrm{z}$, respectively (Figure 2b), as well as MS/MS analysis (Figure 2c). Ionization under nano-electrospray ionization (ESI) conditions favored the singly charged $[\mathrm{M}+\mathrm{H}]$ precursor with approximately 2.5 -fold higher intensity in the extracted ion chromatogram (XIC) of $[\mathrm{M}+\mathrm{H}]$ versus $[\mathrm{M}+2 \mathrm{H}]$. Monitoring the ratio of singly to doubly charged precursor was determined to be critical to developing a robustness quantitation strategy for TCT.

\subsection{MS/MS Analysis of TCT}

Tandem MS fragmentation by high-energy C-trap dissociation (HCD) generated similar fragment ions to those previously observed by fast atom bombardment mass spectrometry (FAB-MS) of TCT from B. pertussis $[29,30]$. Since HCD fragmentation applies a normalized collision energy based on precursor $\mathrm{m} / \mathrm{z}$, a lower collision energy was applied 
to fragment the doubly charged $[\mathrm{M}+2 \mathrm{H}]$ precursor at $461.6985 \mathrm{~m} / \mathrm{z}$ versus the singly charged $[\mathrm{M}+\mathrm{H}]$ precursor at $922.3893 \mathrm{~m} / \mathrm{z}$. This resulted in predominant detection of peptide backbone fragments from the singly charged $[\mathrm{M}+\mathrm{H}]$ precursor and glycan fragments from the doubly charged $[\mathrm{M}+2 \mathrm{H}]$ precursor, including the signature O-linked $\mathrm{N}$-acetyl glucosamine (O-GlcNAc) ion series at 204, 186, 168, 144, 138, and $126 \mathrm{~m} / \mathrm{z}$ [31]. All detected MS/MS fragment ions were singly charged (see fragment ion table in Supplement S6). Fragmentation at oxygen-linked glycosidic and $\mathrm{N}$-terminal to amide bonds yielded transfer of a proton to the observed ion (Figure 3). Dissociation in the peptide portion of the molecule yielded C-terminal fragments at $719.3073 \mathrm{~m} / \mathrm{z}, 701.2969 \mathrm{~m} / \mathrm{z}$, and $534.2393 \mathrm{~m} / \mathrm{z}$ indicating loss of N-acetylglucosamine, GlcNAc + oxygen, and the entire 1-6-anhydro disaccharide with GlcNAc + N-acetylmuramic (MurNac), respectively.

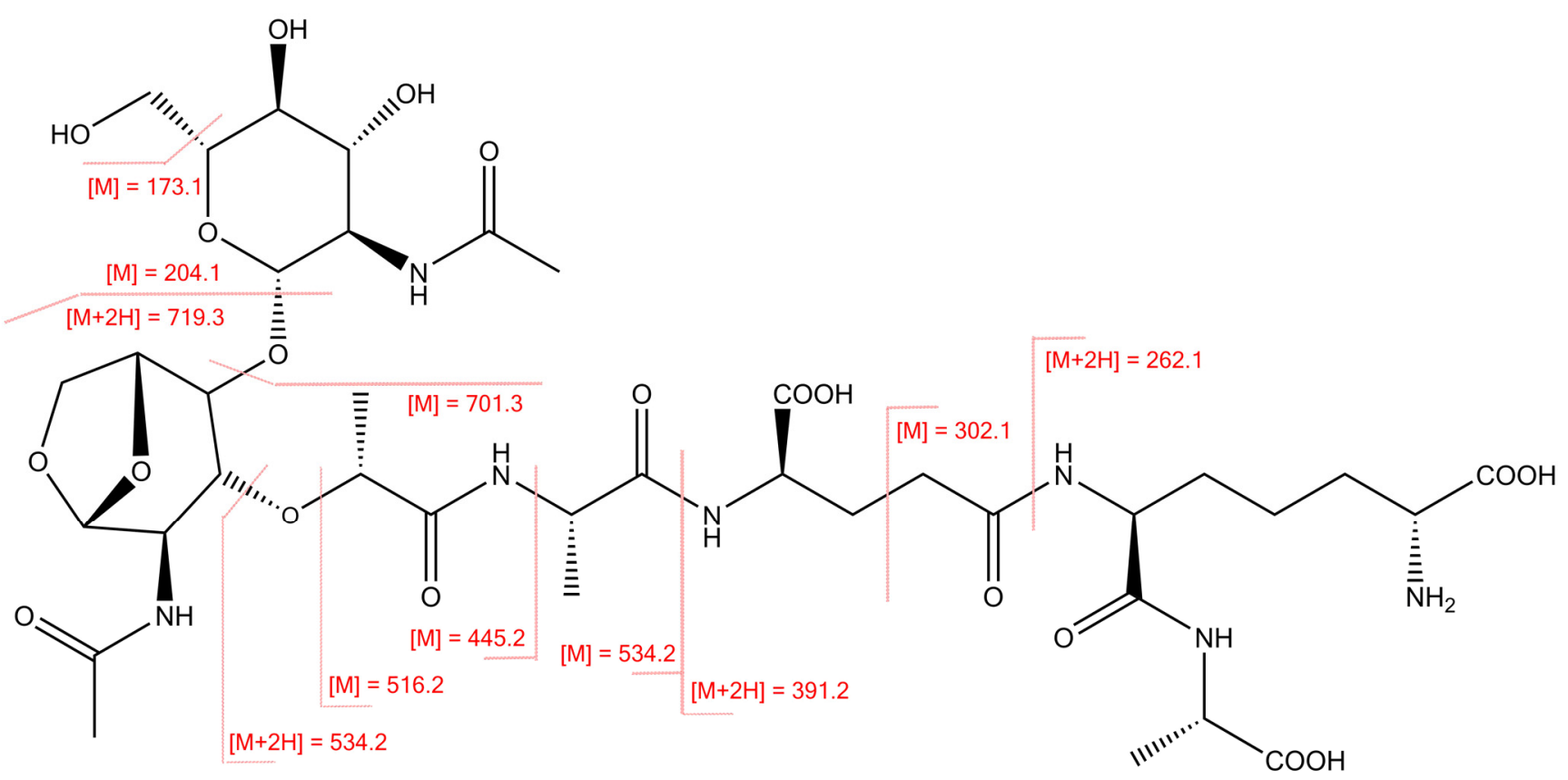

Figure 3. TCT structure and fragment ions generated from high-energy collision induced dissociation (HCD) of the singly charged $[\mathrm{M}+\mathrm{H}]$ precursor ion. Numerical mass values resulting from cleavage along bonds (in red). The " $+2 \mathrm{H}^{\prime}$ notation indicates a proton transfer to the observed ion.

The MS/MS fragmentation pattern observed by HCD (Figure 2c) was similar to that obtained by FAB-MS of TCT from B. pertussis [29]. The most abundant fragment ion in the MS/MS spectra from singly charged TCT precursor was $302.1339 \mathrm{~m} / \mathrm{z}$ (Figure 2c). A fragment ion at $302 \mathrm{~m} / \mathrm{z}$ was previously detected in FAB tandem mass spectrometry of biologically active peptidoglycan monomers from Neisseria gonorrhoeae [32]; however, the $302 \mathrm{~m} / \mathrm{z}$ fragment ion had not been assigned to the TCT sequence. Analysis of the high-resolution MS/MS spectra generated from HCD fragmentation yielded an assignment of this ion to a fragment of the peptide backbone (Figure 3). Other peptide fragments consistent with previously published unit resolution MS/MS spectra $[30,32]$ include the Ala-DAP ion at $262.1392 \mathrm{~m} / \mathrm{z}$ and the Ala-DAP-Glu fragment at $391.1813 \mathrm{~m} / \mathrm{z}$.

\subsection{Multiple Reaction Monitoring (MRM) Analysis}

A MRM method was designed for targeted quantitation of ACT, DNT, and TCT. Surrogate peptides for ACT and DNT were leveraged from the previously published Parallel Reaction Monitoring (PRM) method [27], with one sequence for quantitation and a second for specificity (Table 1). Given similar collision-induced fragmentation mechanisms on Orbitrap and Triple Quadrupole mass spectrometers, it was expected that the highest responding fragment ions from PRM experiments on the Q Exactive HF Orbitrap would be applicable to MRM experiments on the Xevo ${ }^{\mathrm{TM}}$ TQ-S. 
Table 1. Fragment ion transitions for LC-MS/MS (MRM) analysis of ACT, DNT and TCT peptides. Underlined letters indicate incorporation of $\mathrm{N}^{15}$ heavy labelled amino acids.

\begin{tabular}{|c|c|c|c|c|c|c|c|c|}
\hline Toxin & $\begin{array}{c}\text { Theoretical Intact } \\
\text { Molecular Weight } \\
\text { (g/mol) }\end{array}$ & Peptide & $\begin{array}{c}\text { Fragment } \\
\text { Type }\end{array}$ & Description & $\begin{array}{l}\text { Precursor } \\
(\mathrm{m} / \mathrm{z})\end{array}$ & $\begin{array}{c}\text { Fragment } \\
(\mathrm{m} / \mathrm{z})\end{array}$ & Cone (V) & $\begin{array}{l}\text { Collision } \\
\text { Energy (V) }\end{array}$ \\
\hline \multirow{8}{*}{$\mathrm{ACT}$} & \multirow{8}{*}{177414} & \multirow{4}{*}{ NIENAVGSAR ${ }^{A}$} & \multirow{2}{*}{$\mathrm{y} 8 *$} & Native & 515.7674 & 803.4006 & 35 & 19 \\
\hline & & & & $\begin{array}{l}\text { Heavy } \\
\text { AQUA }\end{array}$ & 520.7716 & 813.4089 & 35 & 19 \\
\hline & & & \multirow{2}{*}{ y7 } & Native & 515.7674 & 674.3580 & 35 & 22 \\
\hline & & & & $\begin{array}{l}\text { Heavy } \\
\text { AQUA }\end{array}$ & 520.7716 & 684.3663 & 35 & 22 \\
\hline & & \multirow{4}{*}{ ITGDAQANVLR $^{\text {B }}$} & \multirow{2}{*}{ y9 } & Native & 579.3173 & 943.4956 & 35 & 22 \\
\hline & & & & $\begin{array}{l}\text { Heavy } \\
\text { AQUA }\end{array}$ & 584.3214 & 953.5038 & 35 & 22 \\
\hline & & & \multirow{2}{*}{ y5 } & Native & 579.3173 & 572.3515 & 35 & 22 \\
\hline & & & & $\begin{array}{l}\text { Heavy } \\
\text { AQUA }\end{array}$ & 584.3214 & 582.3597 & 35 & 22 \\
\hline \multirow{8}{*}{ DNT } & \multirow{8}{*}{160644} & \multirow{4}{*}{ ELPALIGASGLR $^{\mathrm{A}}$} & \multirow{2}{*}{$y 6^{*}$} & Native & 598.8535 & 560.3151 & 35 & 21 \\
\hline & & & & $\begin{array}{l}\text { Heavy } \\
\text { AQUA }\end{array}$ & 603.8576 & 570.3234 & 35 & 21 \\
\hline & & & \multirow{2}{*}{ y7 } & Native & 598.8535 & 673.3991 & 35 & 24 \\
\hline & & & & $\begin{array}{l}\text { Heavy } \\
\text { AQUA }\end{array}$ & 603.8576 & 683.4074 & 35 & 24 \\
\hline & & \multirow{4}{*}{ NDDLVSIAATYDR ${ }^{\text {B }}$} & \multirow{2}{*}{ y8 } & Native & 726.8519 & 896.4472 & 35 & 24 \\
\hline & & & & $\begin{array}{l}\text { Heavy } \\
\text { AQUA }\end{array}$ & 731.8560 & 906.4555 & 35 & 24 \\
\hline & & & \multirow{2}{*}{ b3 } & Native & 726.8519 & 345.1041 & 35 & 29 \\
\hline & & & & $\begin{array}{l}\text { Heavy } \\
\text { AQUA }\end{array}$ & 731.8560 & 345.1041 & 35 & 29 \\
\hline \multirow{2}{*}{ TCT } & \multirow{2}{*}{921} & \multirow{2}{*}{$\mathrm{C}_{37} \mathrm{H}_{59} \mathrm{O}_{20} \mathrm{~N}_{7}$} & \multirow{2}{*}{ Peptidoglycan } & {$[\mathrm{M}+\mathrm{H}]$} & 922.3888 & 719.3099 & 35 & 31 \\
\hline & & & & {$[\mathrm{M}+2 \mathrm{H}]$} & 461.6985 & 719.3099 & 35 & 11 \\
\hline
\end{tabular}

A Sequence selected for protein quantitation. ${ }^{\text {B }}$ Sequence selected for confirmation of protein identity (i.e., specificity). ${ }^{*}$ Fragment ion transitions for protein quantitation.

One key difference between PRM and MRM methods, is the use of a fixed normalized collision energy in PRM versus the ability to fine tune collision energy (CE) voltage for each fragment ion in MRM. CE voltage is known to impact fragmentation patterns observed for glycopeptides, denoted by significantly different fragmentation patterns for singly and doubly charged TCT precursors using normalized CE in nanoLC-MS/MS.

Optimization of $\mathrm{CE}$ was performed in three iterative rounds for the top three transitions per ACT/DNT/TCT precursor identified by PRM. Synthetic ACT/DNT AQUA peptides standard $(20 \mathrm{fmol} / \mu \mathrm{L})$ and purified TCT standard $(20 \mathrm{ng} / \mathrm{mL})$ were used to refine $\mathrm{CE}$ values in the MRM method. First, crude optimization of $\mathrm{CE}$ values was performed for TCT with $10 \mathrm{~V}$ steps applied to the singly and doubly charged precursors from 13 to $53 \mathrm{~V}$ for $[\mathrm{M}+\mathrm{H}]$ and 6 to $46 \mathrm{~V}$ for $[\mathrm{M}+2 \mathrm{H}]$ precursor masses. Second, stepped $\mathrm{CE}$ was performed in $1 \mathrm{~V}$ increments ramping $4 \mathrm{~V}$ above and below the Skyline-predicted CE values for $\mathrm{ACT}$ and DNT, and $\pm 4 \mathrm{~V}$ from the values obtained for TCT in round 1. Lastly, CE values were optimized by ramping $\pm 4 \mathrm{~V}$ from $\mathrm{CE}$ value identified as giving highest peak area response in round 2. Following CE-optimization, new heavy and native MRM methods were created with the top two transitions per peptide listed in Table 1.

The LC was reconfigured for MRM; switching from nano $\mathrm{LC}$ run at $300 \mathrm{~nL} / \mathrm{min}$ with a $75 \mu \mathrm{m}$ column internal diameter for PRM, to high-flow UPLC run at $300 \mu \mathrm{L} / \mathrm{min}$ with a $2.1 \mathrm{~mm}$ internal diameter. The use of high-flow chromatography provided several benefits, including much shorter acquisition methods, more robust system performance, and better 
chromatographic behavior for TCT, while maintaining the required sensitivity for detection of the ACT and TCT below the Ph. Eu limits [33].

\subsection{Quantitation by Multiple Reaction Monitoring (MRM)}

The MRM workflow (Figure 1) combined MS-based protein quantitation using surrogate AQUA peptide standards for ACT and DNT, with traditional small molecule quantitation using an external standard curve for TCT. Performance metrics were re-assessed in the MRM method using multiple isotopologue reaction monitoring (MIRM) [34]. The mass resolution setting for the 1st quadrupole (Q1) was adjusted from unit mass resolution with full width at half maximum set to 0.75 (FWHM $=0.75$ ) to a custom MIRM setting (FHWM $=0.5$ ). On tandem quadrupole MS instruments, peptide signal response is inversely proportional to the quadrupole resolution. Therefore, increasing the quadruple resolution decreases the number of ions passing through the instrument (i.e., signal response) but increases specificity for a given precursor-fragment ion transition. Higher specificity is particularly advantageous for complex sample matrices and doubly charged ACT/DNT/TCT peptide precursors with naturally occurring isotopes spaced $0.5 \mathrm{~m} / \mathrm{z}$ apart.

The ACT/DNT AQUA peptides and TCT standard were spiked into a purified PT antigen, and theoretical isotopic abundances calculated for the most abundant transition per peptide. AQUA peptide signal response was determined to be linear with an $R^{2} \geq 0.99$ from 1 to $100 \mathrm{fmol}$ on-column (Supplement S7). The limits of quantitation (LOQ) were determined based on the lowest abundance MIRM channel with $\mathrm{S} / \mathrm{N} \geq 10$ and measured abundance within $20 \%$ of the theoretical isotopic abundance. The limits of detection (LOD) were estimated based on the lowest abundance MIRM channel with $\mathrm{S} / \mathrm{N} \geq 3$ across triplicate measurements (Table 2).

Table 2. MS performance metrics for ACT, DNT, and TCT from MIRM evaluation.

\begin{tabular}{|c|c|c|c|c|c|c|}
\hline \multirow[b]{2}{*}{ Toxin } & \multirow{2}{*}{ Standard Type } & \multirow{2}{*}{$\begin{array}{l}\text { Peptide } \\
\text { Standard }\end{array}$} & \multicolumn{2}{|c|}{ LLOQ $^{1}$} & \multicolumn{2}{|c|}{$\mathrm{LOD}^{2}$} \\
\hline & & & On-Column & $\begin{array}{c}\text { per } 25 \mu \mathrm{g} \\
\text { Digest }\end{array}$ & On-Column & $\begin{array}{l}\text { per } 25 \mu \mathrm{g} \\
\text { Digest }\end{array}$ \\
\hline \multirow{2}{*}{$\mathrm{ACT}$} & \multirow{2}{*}{$\begin{array}{c}\text { Internal-AQUA } \\
\text { peptide standards } \\
(20 \mathrm{fmol} / \mu \mathrm{L})\end{array}$} & NIENAVGSAR & $93.6 \mathrm{amol}$ & $\begin{array}{c}2.6 \mathrm{ng} \\
(14.6 \mathrm{fmol})\end{array}$ & $21.4 \mathrm{amol}$ & $\begin{array}{c}0.59 \mathrm{ng} \\
(3.39 \mathrm{fmol})\end{array}$ \\
\hline & & ITGDAQANVLR & $116 \mathrm{amol}$ & $\begin{array}{c}3.2 \mathrm{ng} \\
(18.1 \mathrm{fmol})\end{array}$ & $63.6 \mathrm{amol}$ & $\begin{array}{c}1.76 \mathrm{ng} \\
(9.92 \mathrm{fmol})\end{array}$ \\
\hline \multirow{2}{*}{ DNT } & \multirow{2}{*}{$\begin{array}{l}\text { Internal-AQUA } \\
\text { peptide standards } \\
(20 \mathrm{fmol} / \mu \mathrm{L})\end{array}$} & NDDLVSIAATYDR & $1.96 \mathrm{fmol}$ & $\begin{array}{c}49.1 \mathrm{ng} \\
(306 \mathrm{fmol})\end{array}$ & $375 \mathrm{amol}$ & $\begin{array}{c}9.4 \mathrm{ng} \\
(58.5 \mathrm{fmol})\end{array}$ \\
\hline & & ELPALIGASGLR & $3.97 \mathrm{fmol}$ & $\begin{array}{c}99.5 \mathrm{ng} \\
\text { (619 fmol) }\end{array}$ & $655 \mathrm{amol}$ & $\begin{array}{c}16.4 \mathrm{ng} \\
(102 \mathrm{fmol})\end{array}$ \\
\hline TCT & $\begin{array}{l}\text { External-purified } \\
\text { TCT standard }\end{array}$ & Purified TCT & $2.3 \mathrm{pg}$ & $\begin{array}{c}0.388 \mathrm{pmol} \\
(0.36 \mathrm{ng})\end{array}$ & $0.423 \mathrm{pg}$ & $\begin{array}{c}0.069 \mathrm{pmol} \\
(63.6 \mathrm{pg})\end{array}$ \\
\hline
\end{tabular}

${ }^{1}$ MIRM channel with $\mathrm{S} / \mathrm{N} \geq 10$ and measured abundance $\pm 20 \%$ theoretic isotopic abundance value. ${ }^{2}$ Lowest channel with $\mathrm{S} / \mathrm{N} \geq 3$ across triplicate MIRM measurements.

Dose-response linearity for TCT was evaluated from plots of peak area vs. TCT concentration $(\mathrm{ng} / \mathrm{mL})$ for an external calibration curve. Comparison of linear versus quadratic fit showed no significant difference in correlation coefficient $\left(R^{2}\right)$ or residuals over three orders of magnitude from 5 to $531 \mathrm{pg}$ TCT (Supplement S8). Using a linear fit, a bias was observed when the calibration range was extended to 4 orders of magnitude. This result was consistent with previous published work suggesting that quadratic fit and $1 / \mathrm{X}^{2}$ weighing is most suitable for bioanalytical LC-MS/MS assays [35]. Use of a quadratic fit resulted in an $R^{2}$ value of 0.9929 from 5.31 to 5314 pg TCT (Supplement S8).

Results of TCT signal response from the external calibration curve revealed that the doubly charged TCT precursor was 3 to 4.5 -fold higher in response than the singly charged precursor under high-flow ESI conditions. This result was contrary to previously 
described PRM results, which demonstrated preferential ionization of the singly charged TCT precursor under nano-ESI conditions. The proportion of singly changed TCT precursor was observed to increase at higher concentrations of TCT. Processing the sum of TCT response from singly and doubly charged precursors lowered the measured variability (i.e., lower \% coefficient of variation $(\% \mathrm{CV})$ ) between replicate injections (supplement S9). To facilitate robust quantitation of TCT, transitions with a common fragment from both the singly and doubly charged TCT precursors were summed in the final MRM method. The fragment ion resulting from loss of GlcNAc was selected as it produced the highest response in both charge states following CE optimization on the Xevo ${ }^{\mathrm{TM}}$ TQ-S (i.e., $922.3893>719.3099+461.6985>719.3099 \mathrm{~m} / \mathrm{z}$ ). No endogenous ACT, DNT, or TCT were detected at the purified PT antigen drug substance (DS) stage using the finalized LC-MS/MS (MRM) method.

\subsection{Method Qualification}

Method performance for ACT and TCT quantitation was evaluated by spiking recombinant ACT standard and purified TCT into purified PT antigen at concentration levels spanning the Ph. Eu. 1356 regulatory limits (Table 3). Method accuracy was assessed by determination of percent recovery from the measured ACT/TCT concentration divided by the theoretical amounts spiked into each sample. The recovery ranged from $81 \%$ to $89 \%$ for ACT and $114 \%$ to $128 \%$ for TCT (Table 3 ).

Table 3. Method qualification results for ACT and TCT in spiked PT antigen drug substance.

\begin{tabular}{|c|c|c|c|c|c|c|c|c|}
\hline \multirow[b]{2}{*}{ Toxin } & \multirow{2}{*}{$\begin{array}{l}\text { Ph. Eu. } \\
\text { 1356 Limit }\end{array}$} & \multirow[b]{2}{*}{$\%$ EU Limit } & \multirow{2}{*}{$\begin{array}{c}\text { Accuracy } \\
\text { (\% Recovery) }\end{array}$} & \multicolumn{2}{|c|}{ Precision $(\% \mathrm{CV})$} & \multirow{2}{*}{ Linearity } & \multirow{2}{*}{$\begin{array}{l}\text { Qualified Range } \\
\text { (per Dose) }\end{array}$} & \multirow{2}{*}{$\begin{array}{c}\text { LLOQ (per } \\
\text { Antigen Dose) }\end{array}$} \\
\hline & & & & Repeatability & $\begin{array}{l}\text { Intermediate } \\
\text { Precision }\end{array}$ & & & \\
\hline \multirow{3}{*}{$\mathrm{ACT}$} & \multirow{3}{*}{$\begin{array}{l}500 \mathrm{ng} \\
\text { per dose }\end{array}$} & $10.0 \%$ & 87 & 2.3 & 5.3 & \multirow{3}{*}{$R^{2}=0.9824$} & \multirow{3}{*}{50.0 to $600.0 \mathrm{ng}$} & \multirow{3}{*}{$14.1 \mathrm{ng}$} \\
\hline & & $50.0 \%$ & 89 & 2.6 & 7.7 & & & \\
\hline & & $120.0 \%$ & 81 & 4.1 & 7.8 & & & \\
\hline \multirow{5}{*}{ TCT } & \multirow{5}{*}{$\begin{array}{l}2 \text { pmol } \\
\text { per dose }\end{array}$} & $20.0 \%$ & 128 & 5.7 & 12.0 & \multirow{5}{*}{$R^{2}=0.9931$} & \multirow{5}{*}{0.4 to $12.8 \mathrm{pmol}$} & \multirow{5}{*}{$0.41 \mathrm{pmol}$} \\
\hline & & $53.1 \%$ & 118 & 5.0 & 9.5 & & & \\
\hline & & $120.0 \%$ & 114 & 2.6 & 4.0 & & & \\
\hline & & $265.7 \%$ & 122 & 1.1 & 5.2 & & & \\
\hline & & $637.7 \%$ & 120 & 0.9 & 6.4 & & & \\
\hline
\end{tabular}

Both repeatability and intermediate precision were assessed at three spike concentration levels for ACT in PT antigen DS. For repeatability at each level, a total of nine determinations obtained across three experimental days were used to calculate a pooled standard deviation. The pooled standard deviation was used to calculate a standard error based on two independent preparations in the reportable value. The $\% \mathrm{CV}$ for repeatability of ACT quantitation using NIENAVGSAR was $2.3 \%$ to $4.1 \%$ for 50.0 to 600.0 ng ACT per dose. The $\% C V$ values for intermediate precision were $\leq 7.8 \%$ for ACT using NIENAVGSAR for quantitation over the range described above. Precision of TCT quantitation was evaluated for five spike concentration levels spanning $20 \%$ to $638 \%$ of the EU limit of 2 pmol per dose (Table 3). The \%CV values for repeatability were $0.9 \%$ to $5.7 \%$ for 0.4 to $12.8 \mathrm{pmol}$ of TCT per antigen dose. The $\% \mathrm{CV}$ values for intermediate precision were $4.0 \%$ to $12.0 \%$ for 0.4 to $12.8 \mathrm{pmol}$ of TCT per dose.

Method linearity was evaluated by plotting measured versus theoretical toxin concentration across the spike levels. Results for ACT content were plotted for nine determinations at three concentration levels, yielding a correlation coefficient $\left(R^{2}\right)$ of 0.9824 for 50 to $600 \mathrm{ng}$ ACT using NIENAVGSAR for quantitation. Linearity was also confirmed for TCT with an $\mathrm{R}^{2}$ of 0.9931 for 0.3684 to $11.7 \mathrm{ng}$ TCT, equivalent to 0.4 to $12.8 \mathrm{pmol}$ per dose. The slope values for ACT and TCT were within the range of 0.8-1.2 (Figure 4), in line with the percent recovery results for method accuracy (Table 3 ). The lower limits for quantitation (LLOQ) 
were calculated based on 10 times the pooled standard deviation from $n=9$ determinations of the lowest spike level. The method LLOQ values of $14.1 \mathrm{ng}$ and $0.41 \mathrm{pmol}$ were well below the EU regulatory limits of $500 \mathrm{ng}$ and 2 pmol per dose, respectively, for ACT and TCT.
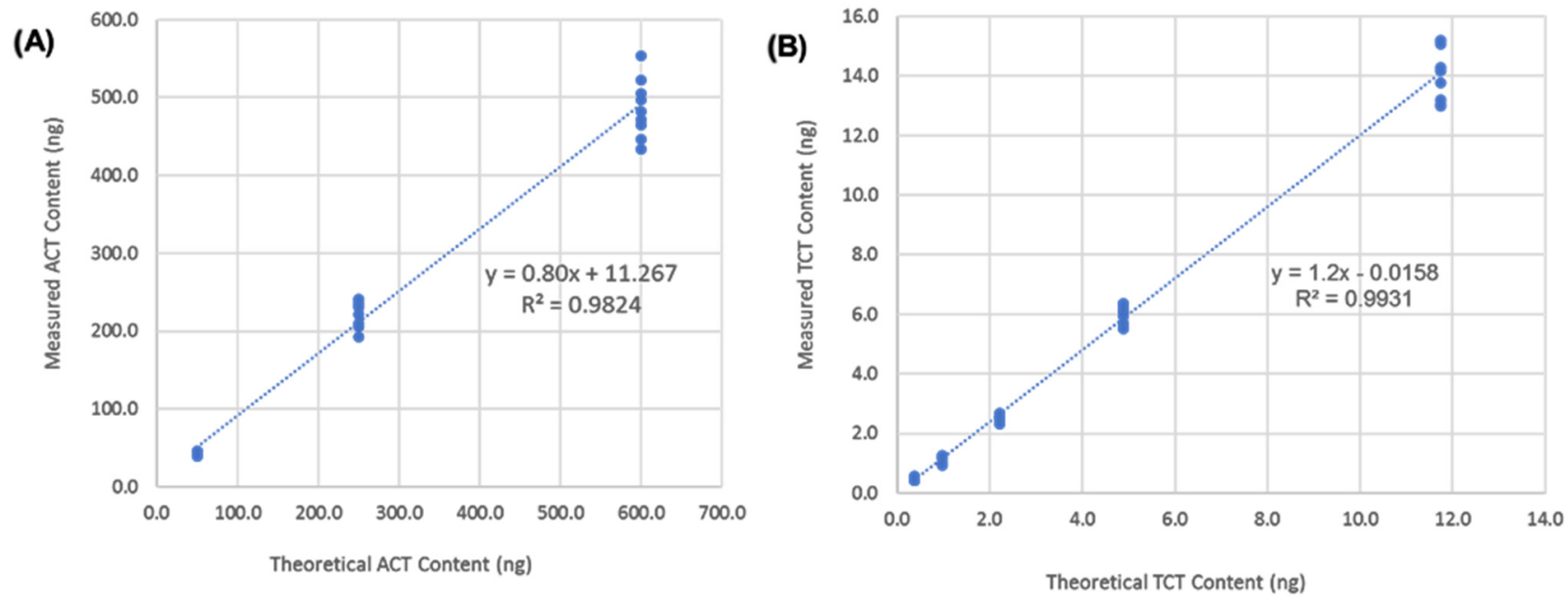

Figure 4. Method linearity for (A) ACT and (B) TCT spiked into PT antigen drug substance samples. Results plotted for $\mathrm{n}=9$ determinations per concentration level.

\section{Discussion}

This work was initiated to develop a quantitative method for routine analysis of $\mathrm{ACT}$ and TCT in aP vaccine antigens at the DS stage, as these toxins have established analytical safety thresholds. The DNT peptide sequences were maintained as standards in the method to allow for in-process monitoring of all three B. pertussis residual toxin within a single workflow.

Prior to development of an LC-MS workflow, analysis of residual B. pertussis toxins required three separate methods. This includes an ELISA or enzymatic test for ACT [24], an HPLC assay for TCT, and animal test for DNT [33]. Development and maintenance of three separate assays is complex and inefficient. In addition, matrix changes may have different effects on the individual assays making analysis of process intermediates challenging to demonstrate toxin clearance. A single quantitative LC-MS method that can detect and quantitate all residual toxins in one workflow would improve efficiency and streamline analysis, testing, and reporting. A total content method is also inherently more stringent than an activity-based assay as it will detect inactive forms of the toxin(s).

We designed this new method by adapting the targeted analysis work reported by Szymkowicz et. al. [27] describing a PRM workflow for protein toxins, ACT and DNT, on a Q-Exactive HF nanoLC-MS/MS system. For the development of a routine test, several additional requirements are typically considered, including system sensitivity, system reliability, assay throughput, ease of analysis, and LC-MS system compliance requirements, which are governed by good manufacturing practices. Given these considerations, we decided to build our quantitative method on a Waters Xevo ${ }^{\mathrm{TM}} \mathrm{TQ}-\mathrm{S}$ coupled to an $\mathrm{H}-$ Class $^{\mathrm{TM}}$ UPLC; a tandem quadrupole system, using standard analytical flow rates and columns. By moving to an analytical flowrate system, we were able to reduce our method acquisition time from $95 \mathrm{~min}$ to $14.5 \mathrm{~min}$ per experiment while maintaining similar overall assay sensitivity.

Protein quantitation by MRM is an established workflow used in academic, clinical, and industrial settings [36,37]. MRM is a targeted workflow that allows for selection of a precursor and fragment pair, called a transition, that is specific to the MS detection of the analyte of interest based on its molecular structure. MRM workflows can be designed for any biomolecule, including peptides and small molecules. The specificity of detection for a 
given analyte can be increased by selecting multiple transitions for each molecule. For our residual toxin quantitation method, we selected two transitions per analyte; one transition to quantitate, the second transition to confirm specificity.

To quantitate proteins by MRM, samples must first be digested using a protease with specific and defined cleavage characteristics. The proteolytic peptides produced during sample digestion are detected in the LC-MS system, providing greater specificity, sensitivity, and accuracy of analysis to the method. It is these peptides, released during sample digestion, that are measured and quantitated during analysis; protein amounts are then inferred.

Tracheal cytotoxin (TCT) is a small glycopeptide released from the B. pertussis cell wall during the logarithmic phase of cell growth [20]. The biomolecule is $921 \mathrm{Da}$ and can be detected directly by MS, however, upstream sample processing (e.g., protein precipitation) is typically used to remove complex protein matrices prior to reverse-phase HPLC (RPHPLC) separation. Recently, a hydrophilic interaction liquid chromatography (HILIC)-MS method was described for quantitation of TCT in pertussis vaccines [38]. Use of HILIC separation yielded improved chromatographic performance, however, the strong organic solvents would not be amendable to analysis of protein toxins, ACT and DNT. In our method with RP-HPLC coupled to MRM, we detect TCT after enzymatic digestion to allow for measurement of all three residual toxins in one workflow (refer to MRM method described in Section 5).

The MRM method was qualified from 50 to $600 \mathrm{ng}$ for ACT and from 0.4 to $12.8 \mathrm{pmol}$ for TCT, well below the EU regulatory limits of $500 \mathrm{ng}$ per dose for ACT, and 2 pmol per dose for TCT [33]. It should be noted that the regulatory limits for ACT and TCT are expressed per dose at the drug product (DP) stage, whereas testing for residual toxins is performed at the purified DS stage prior to the final formulation with adjuvant. Typical doses for aP vaccines can range from 3 to $20 \mu \mathrm{g}$ per antigen component. To address the DSto-DP conversion, the amount of toxin is reported per $\mu \mathrm{g}$ of antigen. A simple calculation is then performed based on the target dose of the specific DP formulation. This approach will allow for broader method applications, where any subset of aP antigens can be tested at the purified DS stage and then the total residual toxin values can be summed according to a specific product formulation(s).

For TCT, we used an external standard that was purified from B. pertussis culture supernatant [29]. In the results, we also included a tandem mass spectrum of TCT (Figure 2) derived from nano LC-MS/MS analysis on the Q-Exactive HF to provide updated fragment assignments supporting transition selection for this analyte in our MRM method. This high mass accuracy MS/MS spectra also allowed us to identify novel fragment features for TCT providing new information for this peptidoglycan component released from the B. pertussis cell wall (Figure 3).

In our sample preparation workflow (Figure 1) we added AQUA heavy peptide standard for ACT and DNT to samples prior to proteolysis with Trypsin/Lys-C. Spike-recovery experiments with ACT and TCT reference standards showed the accuracy and precision of the workflow for these two toxins (Table 3). We also demonstrated that TCT was recovered through the sample preparation protocol (Section 5.3), with no impact from the digestion required for analysis of protein toxins $\mathrm{ACT}$ and DNT.

Protein quantitation using AQUA peptide standards depends on the accuracy of the heavy-labelled synthetic peptides provided by the vendor, as well as the signal stability of both native and synthetic peptides sequences [39]. As the quality requirements increase for an assay, so do the requirements for monitoring the critical reagents in the assay. In-house approaches will be required to monitor the stability of AQUA peptide reagents over time. This may present a number of challenges, as AQUA peptides are typically provided at $5 \mathrm{pmol} / \mu \mathrm{L}$, which is near LOQ for most LC-based amino acid analysis (AAA) workflows. Vendors typically circumvent quantitative limits for AAA by testing purified bulk synthetic peptides, then diluting and aliquoting before shipment to the customer. Quantitative analysis of final stocks is not typically performed. In addition, AAA is not an ideal method 
to monitor peptide stability as the intact molecule is first hydrolyzed in acid to individual amino acid constituents. New approaches will need to be considered as AQUA peptide reagents are implemented in QC batch release tests. RP-HPLC with UV detection could be used to monitor AQUA peptide reagents [40]. Quantitative Nuclear Magnetic Resonance (NMR) may also be an interesting option [41], although access to a system with the desired capabilities could limit widespread use.

Analysis of DNT remains challenging since there is currently no quantitative threshold established for DNT. Existing regulations refer only to the absence of neurotic lesions when mice are administered the equivalent of one vaccine dose [33]. A broader discussion between vaccine manufacturers, regulators, and academic researchers will be needed to establish a quantitative threshold for DNT to support development of alternative in vitro methods [26]. No certified analytical reference standard is currently available for DNT; however, a recently published protocol described production of recombinant DNT that could facilitate screening of alternative cell or immunochemical-based approaches, in addition to quantitative accuracy/precision in MS-based workflows [42]. The detection limit for LC-MS analysis of DNT (Table 2) would need to be improved by an estimated 10 to 100 -fold before MRM workflows can approach the sensitivity of current animal methods.

One strategy that may be able to address the lack of a DNT reference standard is the use of a Quantification conCATamer (QconCAT) construct for MS-based quantitation. QconCAT is an artificial recombinant protein made up of linked, digest-specific, peptide sequences from several proteins [43]. Flanking residues from the native protein sequences can be inserted around the concatenated peptides, to replicate digestion kinetics experienced by protein(s) of interest [44]. These constructs can be expressed in E. coli and spiked into evaluation samples, prior to digestion, to assess method performance metrics such as accuracy and precision across a relevant concentration range. Alternatively, the constructs can be expressed in $\mathrm{N}^{15}$ enriched media to add a metabolic heavy label into every amide bond in the QconCAT sequences. $\mathrm{N}^{15}$ heavy labelling would allow the QconCAT to be used as an internal quantitation standard [45] in lieu of AQUA peptide standards for ACT and DNT.

\section{Conclusions}

In this work, we developed an in vitro method for detection and quantitation of residual B. pertussis toxins, ACT, DNT, and TCT, using a targeted LC-MS (MRM) method. The residual toxin method described by our group previously [27] was transferred to a tandem quadrupole system to facilitate routine analysis requiring higher throughput and the addition of an external calibration curve for TCT. A fully quantitative method is described for ACT and TCT, while DNT detection is currently suitable as a limit test. Method sensitivity was determined to be adequate for monitoring clearance of ACT and TCT below established pharmacopeia limits [23,33]. Additional work is required to establish a quantitative threshold for DNT and increase sensitivity for DNT peptide detection. Collectively, the work highlights qualification of an LC-MS test for residual toxins in a PT antigen, with potential for broad application in the testing and characterization of all aP vaccines.

\section{Materials and Methods}

\subsection{Standard Preparation}

Recombinant ACT for spike-recovery studies was purchased from List Biologics (Campbell, CA, USA Cat \#198L). AQUA peptide standards were custom ordered from Thermo Fisher (Rockford, IL, USA) based on the surrogate peptide sequences selected for nano LC-MS/MS analysis of ACT and DNT in Szymkowicz et. al. [27]. One tryptic peptide was selected for absolute quantitation and a second sequence for confirmation of identity. Each AQUA peptide was synthesized with a ${ }^{15} \mathrm{~N},{ }^{13} \mathrm{C}$ labelled terminal arginine and spiked into protein samples internal standards prior to digestion. Amino acid analysis (AAA) was performed by the vendor on the stock solutions. Peptides were provided in individual aliquots diluted to $5 \mathrm{pmol} / \mu \mathrm{L}$ in $5 \%$ acetonitrile $(\mathrm{ACN})$ in water. 
The TCT reference material was obtained from the Goldman Laboratory (University of North Carolina), following purification from culture supernatant of B. pertussis strain Tohama I or III as described by Cookson et. al. [29]. The TCT standard material was characterized by RP-HPLC and shown to be free of peptide contaminants. Starting concentrations were determined using amino acid analysis.

\subsection{Nano LC-MS/MS Analysis of TCT in B. pertussis Supernatant Harvest}

Supernatant harvest from B. pertussis Tohama I strain was digested with Trypsin/Lys$\mathrm{C}$ as previously described [27]. Prior to nano LC-MS/MS analysis, digest samples were thawed at room temperature and then transferred to low-volume autosampler vials (Waters p/n 186005663CV). Nano LC-MS/MS experiments were run on a Q Exactive High Field (HF) mass spectrometer with an UltiMate 3000 RSLCnano UHPLC system (Thermo Scientific, Bremen, Germany).

The targeted parallel reaction monitoring (PRM) acquisition method previously reported for ACT and DNT [27] was used as a starting point for TCT analysis. $2 \mu \mathrm{g}$ of B. pertussis supernatant harvest digest was loaded onto a C18 trap column ( $\mu$-Precolumn $5 \mathrm{~mm} \times 300 \mu \mathrm{m}$ internal diameter (ID), Thermo Cat \#16054) at $5 \mu \mathrm{L} / \mathrm{min}$ with $99 \% \mathrm{~A} / 1 \% \mathrm{~B}$ $(0.1 \%$ trifluoroacetic acid (TFA) in water/ACN). After $2 \mathrm{~min}$ of on-line desalting/preconcentration, the flow was switched to an EASY-Spray column, $15 \mathrm{~cm} \times 75 \mu \mathrm{m}$ ID, PepMap C18, $3 \mu \mathrm{m}$ analytical column with integrated ESI emitter (Thermo Cat \#ES800). Peptides were eluted at $300 \mathrm{~nL} / \mathrm{min}$ with a 95-min gradient from 1 to $35 \%$ 0.1\% formic acid (FA) in ACN. The total run time was $117 \mathrm{~min}$ with the column temperature set to $45^{\circ} \mathrm{C}$ for the Trap column and $30^{\circ} \mathrm{C}$ for the analytical column. The targeted PRM acquisition method cycled between one Full MS survey scan and $15 \mathrm{MS} / \mathrm{MS}$ scans with a $1.4 \mathrm{~m} / \mathrm{z}$ isolation window. Full MS survey scans were acquired from 380 to $2000 \mathrm{~m} / \mathrm{z}$ with a resolution of 120,000 , automatic gain control (AGC) of $3 \times 10^{6}$, and maximum injection time (maxIT) of $50 \mathrm{~ms}$. MS/MS fragmentation was performed during the PRM scans using a resolution of 120,000 , normalized collision energy (NCE) of 27 , maxIT of $300 \mathrm{~ms}$, and AGC of $2 \times 10^{5}$. ESI source conditions include capillary voltage of $1.9 \mathrm{kV}$, capillary temperature of $275^{\circ} \mathrm{C}$, and $S$ lens RF voltage set to 50.0 .

\subsection{Sample Preparation for LC-MRM}

The ACT and DNT AQUA peptides listed in Table 1 were pooled to a concentration of $1 \mathrm{pmol} / \mu \mathrm{L}$ (per peptide sequence) stabilized in a background of $2 \mathrm{pmol} / \mu \mathrm{L}$ enolase digest (Waters $\mathrm{p} / \mathrm{n}$ 186002325). To normalize for batch-to-batch variation in AQUA peptide concentration, a concatenated (QconCAT) protein construct $[43,45]$ was designed containing ACT and DNT surrogate peptides with six flanking residues from the endogenous protein sequences and a C-terminal histidine tag (refer to Supplement S2). A control sample was prepared with $10 \mu \mathrm{g} / \mathrm{mL}$ of native QconCAT in MassPrep Protein Standard Mix (Waters 186004900). The QconCAT control was digested alongside the samples and analyzed by LC-MS/MS (MRM). The reference AQUA peptide concentrations were calibrated based on the concentration of QconCAT measured by LC-MS/MS (MRM) versus theoretical concentration determined by bicinchoninic acid (BCA) assay [46].

A mastermix was prepared with the following reagents: $15 \mu \mathrm{L}$ of $1 \mathrm{M} \mathrm{ABC}$ ( $\mathrm{pH} 7.4$ to 7.5), $15 \mu \mathrm{L}$ of $1 \%$ RapiGest $^{\mathrm{TM}}$ ( $v / v$, Waters, $\left.\mathrm{p} / \mathrm{n} \# 186001860\right), 1.5 \mu \mathrm{L}$ of $500 \mathrm{mM}$ tris(2-carboxyethyl) phosphine solution (Thermo Scientific, Cat \#77720), 15.0 $\mu \mathrm{L}$ of $200 \mathrm{mM}$ chloroacetamide (Thermo Scientific A39270) and $3.12 \mu \mathrm{L}$ of pooled ACT/DNT AQUA peptide stock solution. $25 \mu \mathrm{g}$ of purified antigen was added to the mastermix and completed to $145 \mu \mathrm{L}$ with LC-MS grade water. Each sample was digested in duplicate. Samples were reduced/alkylated by incubating at $95{ }^{\circ} \mathrm{C}$ for $10 \mathrm{~min}$ in a thermomixer set to $300 \mathrm{rpm}$. The reduced and alkylated samples were enzymatically digested by adding $5.0 \mu \mathrm{L}$ of $0.5 \mu \mathrm{g} / \mu \mathrm{L}$ Trypsin/Lys$\mathrm{C}$ proteolytic mixture [47] for $3 \mathrm{~h}$ at $37^{\circ} \mathrm{C}$ using a thermomixer incubator set to $300 \mathrm{rpm}$ for mixing. The digests were quenched with the addition of $6.0 \mu \mathrm{L}$ of TFA (Pierce, Cat \#28904), bringing the total digest volume to $156 \mu \mathrm{L}$ and theoretical concentration of AQUA peptides 
standards to $20 \mathrm{fmol} / \mu \mathrm{L}$ per peptide. The acidified digest samples were confirmed to have a pH of $\sim 2$ using a pH strip and were then incubated at $37^{\circ} \mathrm{C}$ for $30 \mathrm{~min}$ then centrifuged at $8100 \times \mathrm{g}$ for $10 \mathrm{~min}$ to facilitate RapiGest ${ }^{\mathrm{TM}}$ hydrolysis [48]. Digest supernatants were transferred to new tubes and stored at $-80{ }^{\circ} \mathrm{C}$ until LC-MS analysis.

\subsection{LC-MRM Experimental Design}

The availability of high-confidence MS/MS spectra from previous work on the QExactive HF Orbitrap Mass Spectrometer (Thermo Scientific, Bremen, Germany) [27] meant that a relatively small number of transitions for each sequence could be selected for implementation of a higher throughput MRM method. The top three fragments identified for each peptide/precursor in previous targeted MS/MS (PRM) experiments were selected for optimization on the Xevo ${ }^{\mathrm{TM}}$ TQ-S Mass Spectrometer (Milford, MA, USA).

For spike-recovery experiments, recombinant ACT and purified TCT standard were spiked into PT antigen material at concentrations corresponding to $10 \%, 50 \%$, and $120 \%$ of the EU regulatory limits [33]. Each spike sample was aliquoted, stored at $\leq-60{ }^{\circ} \mathrm{C}$, then digested in triplicate on three separate days for a total of nine independent replicates per level.

\subsection{LC-MRM Data Acquisition}

Before MS analysis, sample digests were thawed at room temperature and then transferred to low volume autosampler vials. LC-MS/MS (MRM) experiments were run on a Xevo ${ }^{\mathrm{TM}}$ TQ-S MS system with an ACQUITY H-Class analytical UPLC (Waters Corporation, Milford, MA, USA). Experiments were run on a ACQUITY UPLC BEH

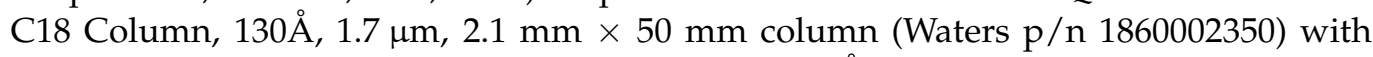

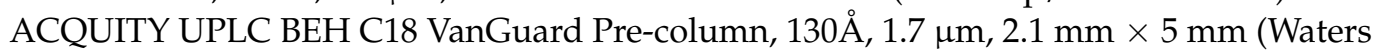
$\mathrm{p} / \mathrm{n}$ 186003975). As with the nanoLC experiments, mobile phases consisted of water (mobile phase A) and $\mathrm{ACN}$ (mobile phase B) with $0.1 \%$ FA added as an ion-pairing agent. Peptides were eluted at $0.3 \mathrm{~mL} / \mathrm{min}$ using 5-min gradient from 1 to $30 \% 0.1 \% \mathrm{FA}$ in ACN. The total run time was $14.5 \mathrm{~min}$. Additional MS tune and LC method gradient details are provided in Supplement S3 and S5, respectively.

An external TCT calibration curve was prepared by diluting purified TCT standard in $0.1 \%$ FA in water to yield five concentration levels at $1,10,40,70$, and $100 \mathrm{ng} / \mathrm{mL}$, respectively. Each TCT calibration level was injected at the beginning and end of the sample set, with the response averaged to generate a calibration curve. All digest samples, standards, and blank injections were analyzed with $1 \mu \mathrm{L}$ injections. A cleaning run was performed between each set of duplicate samples, consisting of a $10 \mu \mathrm{L}$ injection of water/acetonitrile/methanol/isopropyl alcohol (1:1:1:1) and three sawtooth gradients oscillating between 1\% and 95\% B (Supplement S4).

\subsection{Data Analysis}

Raw files from the Themo Q-Exactive HF were analyzed in Qual Browser (Thermo Scientific). Skyline v4.1 was used to refine the CE applied to each transition [49]. After MRM method optimization, data processing was carried out in TargetLynx software (version 4.1, Waters Corporation). For ACT and DNT, the ratio of native-to-heavy peak areas was calculated for each peptide based on the transitions listed in Table 1. Concentrations were determined from the native-to-heavy ratio given the known concentration of heavy peptide standards spiked into the samples. One peptide sequence per protein was used for absolute quantitation and a second for confirmation of identity. The precursor-fragment transition yielding the highest intensity was selected for quantitation in the finalized method (Table 1). For TCT, transitions from the singly and doubly charged precursors were summed to account for variation during ionization. TCT quantitation was performed by comparing signal response in the samples against an external calibration curve. 
Supplementary Materials: The following are available online at https: / www.mdpi.com/article/ 10.3390/toxins13110763/s1, Supplement S1. Ph. Eur. 1356 Limits for Residual Toxins ACT, DNT, and TCT per dose of acellular Pertussis vaccine. Supplement S2. Concatenated QconCAT protein construct containing ACT and DNT peptide sequences. Supplement S3. Tune and inlet settings for the LC-MRM method on a Water Acquity H-class analytical UPLC and Xevo ${ }^{\mathrm{TM}}$ TQ-S mass spectrometer. Supplement S4. Triple sawtooth LC gradient for column cleaning between samples. Supplement S5. Optimized MS method for multiple reaction monitoring (MRM) analysis of ACT, DNT and TCT analysis on the Xevo ${ }^{\mathrm{TM}}$ TQ-S. Supplement S6. TCT fragment ions from high-energy collision induced dissociation (HCD) on a Q-Exactive HF Orbitrap mass spectrometer. Supplement S7. Dose linearity for ACT AQUA peptide standards. Supplement S8. External TCT calibration curves using the singly and doubly charged fragment ion transitions. Supplement S9. TCT signal response from a multi-sample external calibration curve analyzed by MRM. References [32,45] are cited in the supplementary materials.

Author Contributions: Conceptualization, L.S., D.A.J.; methodology, L.S., B.M., W.W.V.T., J.G., D.A.J.; formal analysis, L.S., B.M., W.W.V.T.; data curation \& visualization, L.S.; writing-original draft preparation, L.S., J.G., D.A.J.; writing-review and editing, L.S., B.M., W.W.V.T., J.G., D.A.J.; supervision, J.G., D.A.J. All authors have read and agreed to the published version of the manuscript.

Funding: This study was funded by Sanofi Pasteur Canada. LS was also supported by the Natural Sciences and Engineering Research Council of Canada (NSERC) through a Collaborative Research and Development grant (485321-15) with Sanofi Pasteur Canada as a contributing partner.

Institutional Review Board Statement: Not applicable.

Informed Consent Statement: Not applicable.

Acknowledgments: We thank Zoe Virion, Patrick Farrell, Sabrina Chung and Tao Yuan from the Bioprocess R\&D group for generation of the concatenated (QconCAT) protein construct. Further, Daniel Prevedel and Julia Telychko for preparation of the supernatant harvest and purified antigen samples. We also thank Neil Blackburn from the Sanofi Pasteur CMC team and Voislav Blagojevic from York University for helpful discussions supporting data interpretation. Initial nanoLC-MS/MS experiments for TCT were performed when L.S. was a graduate student under co-supervision of Derek J Wilson at York University.

Conflicts of Interest: L.S. was a graduate student at York University during execution of nanoLCMS/MS experiments for TCT. L.S. is now an employee of Sanofi Pasteur Ltd. Canada. B.M., V.T., J.G. and D.A.J. are employees of Sanofi Pasteur Ltd. Canada and may hold shares and/or stock options in the company. All authors declare no competing interests.

\section{References}

1. Snyder, A. Leila Denmark. Lancet 2012, 379, 2336. [CrossRef]

2. Shapiro-Shapin, C.G. Pearl Kendrick, Grace Eldering, and the Pertussis Vaccine. Emerg. Infect. Dis. 2010, 16, 1273-1278. [CrossRef] [PubMed]

3. Greco, D.; Salmaso, S.; Mastrantonio, P.; Giuliano, M.; Tozzi, A.E.; Anemona, A.; Ciofi degli Atti, M.L.; Giammanco, A.; Panei, P.; Blackwelder, W.C.; et al. A Controlled Trial of Two Acellular Vaccines and One Whole-Cell Vaccine against Pertussis. N. Engl. J. Med. 1996, 334, 341-349. [CrossRef] [PubMed]

4. Cherry, J.D. Pertussis: Challenges Today and for the Future. PLoS Pathog. 2013, 9, e1003418. [CrossRef] [PubMed]

5. Melvin, J.A.; Scheller, E.V.; Miller, J.F.; Cotter, P.A. Bordetella Pertussis Pathogenesis: Current and Future Challenges. Nat. Rev. Microbiol. 2014, 12, 274-288. [CrossRef]

6. Yeung, K.H.T.; Duclos, P.; Nelson, E.A.S.; Hutubessy, R.C.W. An Update of the Global Burden of Pertussis in Children Younger than 5 Years: A Modelling Study. Lancet Infect. Dis. 2017, 17, 974-980. [CrossRef]

7. Clark, T.A. Changing Pertussis Epidemiology: Everything Old Is New Again. J. Infect. Dis. 2014, 209, 978-981. [CrossRef] [PubMed]

8. Zerbo, O.; Bartlett, J.; Goddard, K.; Fireman, B.; Lewis, E.; Klein, N.P. Acellular Pertussis Vaccine Effectiveness Over Time. Pediatrics 2019, 144. [CrossRef]

9. Pertussis: A Disease Affecting All Ages-American Family Physician. Available online: https://www.aafp.org/afp/2006/0801/ p420.html (accessed on 6 August 2021).

10. Schwartz, K.L.; Kwong, J.C.; Deeks, S.L.; Campitelli, M.A.; Jamieson, F.B.; Marchand-Austin, A.; Stukel, T.A.; Rosella, L.; Daneman, N.; Bolotin, S.; et al. Effectiveness of Pertussis Vaccination and Duration of Immunity. CMAJ Can. Med. Assoc. J. 2016, 188, E399-E406. [CrossRef] 
11. Meade, B.D.; Plotkin, S.A.; Locht, C. Possible Options for New Pertussis Vaccines. J. Infect. Dis. 2014, 209 (Suppl. 1), S24-S27. [CrossRef] [PubMed]

12. Ladant, D. Bioengineering of Bordetella Pertussis Adenylate Cyclase Toxin for Vaccine Development and Other Biotechnological Purposes. Toxins 2021, 13, 83. [CrossRef] [PubMed]

13. Xu, Y.; Tan, Y.; Asokanathan, C.; Zhang, S.; Xing, D.; Wang, J. Characterization of Co-Purified Acellular Pertussis Vaccines. Hum. Vaccines Immunother. 2015, 11, 421-427. [CrossRef] [PubMed]

14. Scheller, E.V.; Cotter, P.A. Bordetella Filamentous Hemagglutinin and Fimbriae: Critical Adhesins with Unrealized Vaccine Potential. Pathog. Dis. 2015, 73, ftv079. [CrossRef]

15. Li, Z.; Zhang, Y.; Wang, Q.; Li, Z.; Liu, Y.; Zhang, S.; Zhang, G.; Ma, G.; Luo, J.; Su, Z. Purification Design and Practice for Pertactin, the Third Component of Acellular Pertussis Vaccine, from Bordetella Pertussis. Vaccine 2016, 34, 4032-4039. [CrossRef]

16. Carbonetti, N.H. Pertussis Toxin and Adenylate Cyclase Toxin: Key Virulence Factors of Bordetella Pertussis and Cell Biology Tools. Future Microbiol. 2010, 5, 455-469. [CrossRef] [PubMed]

17. Guiso, N. Bordetella Adenylate Cyclase-Hemolysin Toxins. Toxins 2017, 9, 277. [CrossRef]

18. Teruya, S.; Hiramatsu, Y.; Nakamura, K.; Fukui-Miyazaki, A.; Tsukamoto, K.; Shinoda, N.; Motooka, D.; Nakamura, S.; Ishigaki, K.; Shinzawa, N.; et al. Bordetella Dermonecrotic Toxin Is a Neurotropic Virulence Factor That Uses CaV3.1 as the Cell Surface Receptor. mBio 2020, 11, e03146-19. [CrossRef]

19. Fukui, A.; Horiguchi, Y. Bordetella Dermonecrotic Toxin Exerting Toxicity through Activation of the Small GTPase Rho. J. Biochem. 2004, 136, 415-419. [CrossRef]

20. Goldman, W.E.; Klapper, D.G.; Baseman, J.B. Detection, Isolation, and Analysis of a Released Bordetella Pertussis Product Toxic to Cultured Tracheal Cells. Infect. Immun. 1982, 36, 782-794. [CrossRef]

21. Luker, K.E.; Collier, J.L.; Kolodziej, E.W.; Marshall, G.R.; Goldman, W.E. Bordetella Pertussis Tracheal Cytotoxin and Other Muramyl Peptides: Distinct Structure-Activity Relationships for Respiratory Epithelial Cytopathology. Proc. Natl. Acad. Sci. USA 1993, 90, 2365-2369. [CrossRef]

22. Locht, C. Molecular Aspects of Bordetella Pertussis Pathogenesis. Int. Microbiol. Off. J. Span. Soc. Microbiol. 1999, 2, 137-144.

23. Recommendations to Assure the Quality, Safety and Efficacy of Acellular Pertussis Vaccines; WHO Technical Report Series No. 979; World Health Organization: Geneva, Switzerland, 2013.

24. Eby, J.C.; Gray, M.C.; Warfel, J.M.; Paddock, C.D.; Jones, T.F.; Day, S.R.; Bowden, J.; Poulter, M.D.; Donato, G.M.; Merkel, T.J.; et al. Quantification of the Adenylate Cyclase Toxin of Bordetella Pertussis In Vitro and during Respiratory Infection. Infect. Immun. 2013, 81, 1390-1398. [CrossRef] [PubMed]

25. Publication Office of the European Union. Replacement, Reduction and Refinement of Animal Testing in the Quality Control of Human Vaccines: Brief Description of Ongoing Projects. Available online: http://op.europa.eu/en/publication-detail/-/ publication/42c3a466-bf43-11e5-9e54-01aa75ed71a1/language-en (accessed on 24 April 2020).

26. Uhlrich, S.; Coppens, E.; Moysan, F.; Nelson, S.; Nougarede, N. 3Rs in Quality Control of Human Vaccines: Opportunities and Barriers. In Alternatives to Animal Testing; Kojima, H., Seidle, T., Spielmann, H., Eds.; Springer: Singapore, 2019 ; pp. 76-82. [CrossRef]

27. Szymkowicz, L.; Wilson, D.J.; James, D.A. Development of a Targeted NanoLC-MS/MS Method for Quantitation of Residual Toxins from Bordetella Pertussis. J. Pharm. Biomed. Anal. 2020, 188, 113395. [CrossRef]

28. Kawasaki, A.; Karasudani, Y.; Otsuka, Y.; Hasegawa, M.; Inohara, N.; Fujimoto, Y.; Fukase, K. Synthesis of Diaminopimelic Acid Containing Peptidoglycan Fragments and Tracheal Cytotoxin (TCT) and Investigation of Their Biological Functions. Chem. Weinh. Bergstr. Ger. 2008, 14, 10318-10330. [CrossRef] [PubMed]

29. Cookson, B.T.; Tyler, A.N.; Goldman, W.E. Primary Structure of the Peptidoglycan-Derived Tracheal Cytotoxin of Bordetella Pertussis. Biochemistry 1989, 28, 1744-1749. [CrossRef]

30. Goldman, W.E.; Cookson, B.T. Structure and Functions of the Bordetella Tracheal Cytotoxin. Tokai J. Exp. Clin. Med. 1988, 13, 187-191.

31. Zhao, P.; Viner, R.; Teo, C.F.; Boons, G.-J.; Horn, D.; Wells, L. Combining High-Energy C-Trap Dissociation and Electron Transfer Dissociation for Protein O-GlcNAc Modification Site Assignment. J. Proteome Res. 2011, 10, 4088-4104. [CrossRef]

32. Martin, S.A.; Rosenthal, R.S.; Biemann, K. Fast Atom Bombardment Mass Spectrometry and Tandem Mass Spectrometry of Biologically Active Peptidoglycan Monomers from Neisseria Gonorrhoeae. J. Biol. Chem. 1987, 262, 7514-7522. [CrossRef]

33. European Pharmacopoeia. Current Edition European Monograph for Adsorbed Pertussis Vaccines (Acellular Component); Council of Europe: Strasbourg, France, 2013; p. 1356.

34. Gu, H.; Zhao, Y.; DeMichele, M.; Zheng, N.; Zhang, Y.J.; Pillutla, R.; Zeng, J. In-Sample Calibration Curve Using Multiple Isotopologue Reaction Monitoring of a Stable Isotopically Labeled Analyte for Instant LC-MS/MS Bioanalysis and Quantitative Proteomics. Anal. Chem. 2019, 91, 2536-2543. [CrossRef] [PubMed]

35. Gu, H.; Liu, G.; Wang, J.; Aubry, A.-F.; Arnold, M.E. Selecting the Correct Weighting Factors for Linear and Quadratic Calibration Curves with Least-Squares Regression Algorithm in Bioanalytical LC-MS/MS Assays and Impacts of Using Incorrect Weighting Factors on Curve Stability, Data Quality, and Assay Performance. Anal. Chem. 2014, 86, 8959-8966. [CrossRef] [PubMed]

36. Picotti, P.; Aebersold, R. Selected Reaction Monitoring-Based Proteomics: Workflows, Potential, Pitfalls and Future Directions. Nat. Methods 2012, 9, 555-566. [CrossRef] [PubMed] 
37. Schmidt, A.; Kellermann, J.; Lottspeich, F. A Novel Strategy for Quantitative Proteomics Using Isotope-Coded Protein Labels. Proteomics 2005, 5, 4-15. [CrossRef] [PubMed]

38. Long, Z.; Wei, C.; Guo, Z.; Ma, X.; Li, Y.; Yao, J.; Ji, F.; Li, C.; Huang, T. Determination of tracheal cytotoxin in pertussis and diphtheria tetanus acellular pertussis vaccines using liquid chromatography-tandem mass spectrometry. Se Pu Chin. J. Chromatogr. 2019, 37, 155-161. [CrossRef] [PubMed]

39. Shuford, C.M.; Walters, J.J.; Holland, P.M.; Sreenivasan, U.; Askari, N.; Ray, K.; Grant, R.P. Absolute Protein Quantification by Mass Spectrometry: Not as Simple as Advertised. Anal. Chem. 2017, 89, 7406-7415. [CrossRef]

40. Kuipers, B.J.H.; Gruppen, H. Prediction of Molar Extinction Coefficients of Proteins and Peptides Using UV Absorption of the Constituent Amino Acids at 214 Nm To Enable Quantitative Reverse Phase High-Performance Liquid Chromatography-Mass Spectrometry Analysis. J. Agric. Food Chem. 2007, 55, 5445-5451. [CrossRef]

41. Li, C.; Bhavaraju, S.; Thibeault, M.-P.; Melanson, J.; Blomgren, A.; Rundlöf, T.; Kilpatrick, E.; Swann, C.J.; Rudd, T.; Aubin, Y.; et al. Survey of Peptide Quantification Methods and Comparison of Their Reproducibility: A Case Study Using Oxytocin. J. Pharm. Biomed. Anal. 2019, 166, 105-112. [CrossRef] [PubMed]

42. Stanek, O.; Linhartova, I.; Holubova, J.; Bumba, L.; Gardian, Z.; Malandra, A.; Bockova, B.; Teruya, S.; Horiguchi, Y.; Osicka, R.; et al. Production of Highly Active Recombinant Dermonecrotic Toxin of Bordetella Pertussis. Toxins 2020, 12, 596. [CrossRef]

43. Pratt, J.M.; Simpson, D.M.; Doherty, M.K.; Rivers, J.; Gaskell, S.J.; Beynon, R.J. Multiplexed Absolute Quantification for Proteomics Using Concatenated Signature Peptides Encoded by QconCAT Genes. Nat. Protoc. 2006, 1, 1029-1043. [CrossRef]

44. Cheung, C.S.F.; Anderson, K.W.; Wang, M.; Turko, I.V. Natural Flanking Sequences for Peptides Included in a Quantification Concatamer Internal Standard. Anal. Chem. 2015, 87, 1097-1102. [CrossRef]

45. Scott, K.B.; Turko, I.V.; Phinney, K.W. Chapter Eleven-QconCAT: Internal Standard for Protein Quantification. In Methods in Enzymology; Kelman, Z., Ed.; Isotope Labeling of Biomolecules-Applications; Academic Press: Cambridge, MA, USA, 2016; Volume 566, pp. 289-303. [CrossRef]

46. Smith, P.K.; Krohn, R.I.; Hermanson, G.T.; Mallia, A.K.; Gartner, F.H.; Provenzano, M.D.; Fujimoto, E.K.; Goeke, N.M.; Olson, B.J.; Klenk, D.C. Measurement of Protein Using Bicinchoninic Acid. Anal. Biochem. 1985, 150, 76-85. [CrossRef]

47. Saveliev, S.; Bratz, M.; Zubarev, R.; Szapacs, M.; Budamgunta, H.; Urh, M. Trypsin/Lys-C Protease Mix for Enhanced Protein Mass Spectrometry Analysis. Nat. Methods 2013, 10, 1134. [CrossRef]

48. Yu, Y.-Q.; Gilar, M.; Lee, P.J.; Bouvier, E.S.P.; Gebler, J.C. Enzyme-Friendly, Mass Spectrometry-Compatible Surfactant for in-Solution Enzymatic Digestion of Proteins. Anal. Chem. 2003, 75, 6023-6028. [CrossRef] [PubMed]

49. MacLean, B.; Tomazela, D.M.; Shulman, N.; Chambers, M.; Finney, G.L.; Frewen, B.; Kern, R.; Tabb, D.L.; Liebler, D.C.; MacCoss, M.J. Skyline: An Open Source Document Editor for Creating and Analyzing Targeted Proteomics Experiments. Bioinformatics 2010, 26, 966-968. [CrossRef] [PubMed] 